\title{
A scientific note on the association of Cychramus luteus (Coleoptera: Nitidulidae) with honeybee (Apis mellifera) colonies
}

\author{
Peter NEUMANN ${ }^{\mathrm{a}, \mathrm{b} *}$, Wolfgang RITTER $^{\mathrm{c} * *}$ \\ a Institut für Zoologie, Martin-Luther-Universität Halle-Wittenberg, Hoher Weg 4, 06099 Halle (Saale), Germany \\ b Department of Zoology and Entomology, Rhodes University, Grahamstown 6140, South Africa \\ ${ }^{\mathrm{c}}$ Chemisches und Veterinäruntersuchungsamt Freiburg (CUVUA), Fachgebiet Bienen, \\ Am Moosweiher 2, 79108 Freiburg, Germany
}

(Received 18 December 2003; revised 1 March 2004; accepted 18 March 2004)

Apis mellifera / Cychramus luteus / pest diagnosis / honeybee / Nitidulidae

The small hive beetle, Aethina tumida Murray (Coleoptera: Nitidulidae), has recently become an invasive species in populations of European derived honeybees, Apis mellifera L., and can cause considerable damage to local apiculture (Neumann and Elzen, 2004). It was previously reported that this is the only Nitidulid species, which is associated with honeybee colonies (Toumanoff 1939; Caron, 1978; Hepburn and Radloff, 1998). Here we report for the first time of the association of Cychramus luteus Fabricius (Coleoptera: Nitidulidae) with honeybee colonies. C. luteus is common in Europe and adults feed mainly on pollen (Horion, 1960; Freude et al., 1967). At first sight, C. luteus can easily be confused with the small hive beetle, especially with freshly emerged adults (Lundie, 1940; Freude et al., 1967; Habeck, 2002), due to its size, basic morphology (Fig. 1) and brownish red body coloration.

In May 2003, 12 adult Nitidulid beetles were observed on the bottom board of one hive and 15 in another hive each containing strong $A$. m. carnica colonies ( 20 frames of brood) in an apiary close to Freiburg (im Breisgau), Germany. The beetles were identified as $C$. luteus (Coleoptera: Nitidulidae) based on definitive morphological characteristics (e.g. shape of ovipositor and antennae, colouration of pronotum and elytra, etc.; see Freude et al., 1967; Fig. 1). Similar to A. tumida (Neumann and Elzen, 2004), the beetles were hiding in the hive. They were found underneath the net of the hive insert, which is used in Germany to count the number of dead Varroa destructor mites after treatment. This apiary was located in a pasture within a forest (mainly Fagus sylvatica and Pinus spp.). Several $C$. luteus adults were found feeding on flowers (Taraxacum officinale and Ranunculus spp.) within a distance of $100 \mathrm{~m}$ of the apiary. All colonies $(\mathrm{N}=5)$ at this apiary were carefully investigated. Not a single colony showed beetle larvae, comb damage or fermented honey as known from small hive beetle infestations (Neumann and Elzen, 2004).

Twenty $C$. luteus adults were collected from flowers around the apiary and from inside of the two colonies and introduced into two small plastic containers $(\mathrm{N}=10$ beetles each; size $=15 \mathrm{~cm} \times 10 \mathrm{~cm} \times 5 \mathrm{~cm})$. The containers were provided with small pieces of comb $[10 \mathrm{~cm} \times 10 \mathrm{~cm}]$ containing sealed honeybee brood, pollen or honey, similar to the standard laboratory rearing conditions for A. tumida (Neumann et al., 2001). The containers were incubated in a dark climate chamber at $25^{\circ} \mathrm{C}$ and $60 \%$ relative humidity, which was only opened for the controls. After one week, both containers were carefully screened. Four beetles were still alive and 20 brood cells with pupae were nearly completely opened. However, neither damaged pupae nor beetle eggs or larvae were observed. This contrasts to A. tumida, which opens only small gaps in sealed honeybee brood cells for oviposition on the pupae (Ellis et al., 2003).

Our observations clearly show that $C$. luteus can be associated with honeybee colonies, underlining the importance of correct diagnosis in honeybee pathology. However, it appears as if these beetles do not reproduce on brood, pollen or honey, even in the absence of honeybees, and that damage to colonies is probably small if not absent. Thus, in contrast to A. tumida, $C$. luteus seems to be a rather harmless associate of honeybees, similar to other beetle species (Caron, 1978), and may only seek shelter or pollen in the hives. Future, apiary surveys should carefully take into account that not every Nitidulid beetle associated with honeybee colonies is necessarily a harmful parasite such as A. tumida.

\footnotetext{
* Corresponding author: p.neumann@zoologie.uni-halle.de

** ritter@beepathology.com
} 

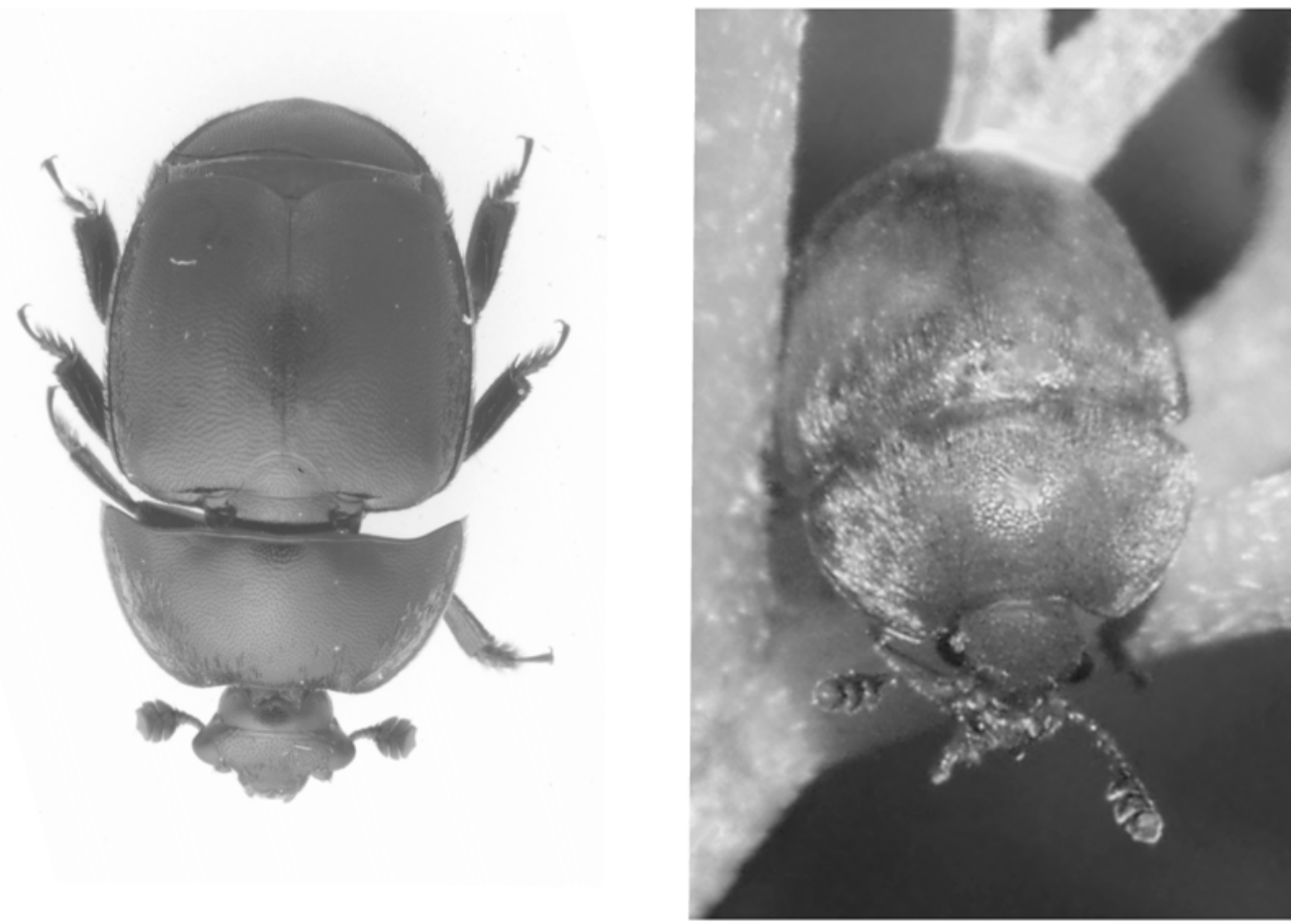

Figure 1. Adult beetles of the family Nitidulidae, which are associated with honeybee colonies (left: $A$. tumida [picture with kind permission Central Science Laboratory National Bee Unit, UK]; right: C. luteus [picture courtesy of F. Koehler]).

\section{ACKNOWLEDGEMENTS}

We wish to thank Frank Baum, Stephan Härtel, Frank Koehler, Sebastian Schornack and Jürgen Schwenkel for their support. Financial support was granted by an Emmy Noether fellowship of the DFG [P.N.].

Note scientifique sur l'association de Cychramus luteus (Coleoptera : Nitidulidae) avec les colonies d'abeilles domestiques (Apis mellifera).

Eine wissenschaftliche Notiz zur Beziehung von Cychramus luteus (Coleoptera: Nitidulidae) mit Honigbienenvölkern (Apis mellifera).

\section{REFERENCES}

Caron D.M. (1978) Other insects, in: Honey bee pests, predators, and diseases, Morse R.A. (Ed.), Cornell University Press, London, pp. 158-196.

Ellis J.D. Jr., Hepburn H.R., Delaplane K.S., Elzen P.J. (2003) A scientific note on small hive beetle (Aethina tumida) oviposition and behaviour during European (Apis mellifera) honey bee clustering and absconding events, J. Apic. Res. 42, 47-48.
Freude H., Harde K.W., Lohse G.A. (1967) Die Käfer Mitteleuropas, Goecke und Evers, Krefeld, p. 72.

Habeck D.H. (2002) Nitidulidae, in: American Beetles, Vol. 2, Arnett R.H., Thomas M.C., Skelley P.E., Frank J.H. (Eds.), CRC Press, Boca Raton, pp. 311-315.

Hepburn H.R., Radloff S.E. (1998) Honeybees of Africa, Springer Verlag, Berlin, Heidelberg, New York.

Horion A.D. (1960) Faunistik der Mitteleuropäischen Käfer, VII/1, Kommissionsverlag Aug. Feyel Überlingen, pp. 125-126.

Lundie A.E. (1940) The small hive beetle Aethina tumida, Science Bulletin 220, Dep. Agr. Forestry, Government Printer, Pretoria, South Africa.

Neumann P., Elzen P.J. (2004) The biology of the small hive beetle (Aethina tumida, Coleoptera: Nitidulidae): Gaps in our knowledge of an invasive species, Apidologie 35, 229-247.

Neumann P., Pirk C.W.W., Hepburn H.R., Elzen P.J., Baxter J.R. (2001) Laboratory rearing of small hive beetles Aethina tumida (Coleoptera: Nitidulidae), J. Apic. Res. 40, 111-112.

Toumanoff C. (1939) Les Ennemies des Abeilles, Imprimerie d'Extrême-Orient, Hanoi, North Vietnam. 